\title{
Acreditación en el programa de Psicología
}

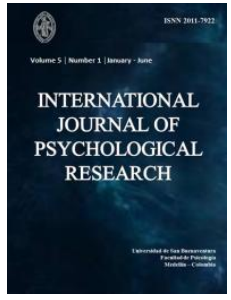

\author{
JORGE Albeiro HERRERA BUILES *,a \\ ${ }^{\text {a }}$ Vicerrector Académico Universidad San Buenaventura-Medellín
}

La editorial INTERNATIONAL JOURNAL OF PSYCHOLOGICAL RESEARCH, sirve como pretexto para referenciar la principal apuesta estratégica de la Universidad de San Buenaventura Seccional Medellín para los próximos años, y es con respecto al proyecto de acreditación de la Institución. Desde su fundación, hace 45 años, esta Alma Mater ha sostenido el compromiso y la responsabilidad con la sociedad, de ofrecer una educación con calidad bajo los principios orientadores de la filosofía franciscana y en permanente perfeccionamiento de la propuesta educativa.

En la búsqueda del ser reconocidos por la calidad, no se propende por el desarrollo y verificación de variables institucionales, para avalar procesos educativos que se rigen bajo patrones de clasificación, categorización, consolidación y verificación de métodos y técnicas que permitan controlar la homogeneidad que avalan el rigor de los procesos institucionales. Por el contrario, es el pretexto para generar las rupturas internas que guíen las transformaciones necesarias hacia la construcción del ideal de Universidad que queremos proyectar.

Es por ello, que en los últimos años, es notorio el empeño de la Institución por fortalecer los procesos académicos e investigativos, aspecto que permitió la acreditación del programa de Psicología, la apertura del Doctorado en Psicología y la indexación de nuestro journal en Scopus. Estos últimos resultados, expresan la pertinencia e impacto de la investigación de la Institución, ante las comunidades científicas del mundo. En este componente, es altamente ponderado el aporte de la Facultad de Psicología en la calidad de la Universidad de San Buenaventura; no sólo por el reconocimiento social de sus egresados, sino por la consolidación de su comunidad académica, congregando las capacidades humanas, científicas y sociales para la contribución al desarrollo social de la región.

El obtener la acreditación del programa de Psicología, permitió potenciar el ejercicio docente e investigativo, as egurando el reconocimiento del mismo en el contexto internacional y proyectando la actualización de la disciplina a la luz de los avances científicos y los cambios de paradigmas que remodelan la sociedad, la cultura y la individuación. En ese sentido, se requiere innovar permanentemente en estrategias educativas y herramientas administrativas que promuevan el avance de la Psicología como profesión de cara a la evolución de la sociedad; esto es, el papel del Psicólogo en el tejido social como mediador de cambios adecuados en los procesos de inter-individuación, como promotor central de la salud mental, como actor principal para promover los estilos de vida saludables integrando las etapas del desarrollo del ser humano, los retos innovadores de las neurociencias y su desarrollo para el descifrar el comportamiento humano, y la formulación de nuevos modelos teórico-prácticos que faciliten intervenciones eficientes para los individuos y los patrones de vulnerabilidad que se suscitan en la vorágine de la cotidianidad humana.

Por tanto, la búsqueda permanente de la excelencia académica seguirá siendo la razón primordial que orientará las decisiones cotidianas y estratégicas de la Universidad, por ello la Institución establece el compromiso con el contexto nacional con la acreditación institucional y de sus programas, como una forma de proyectar el papel de la Universidad de San Buenaventura en los contextos social, económico, productivo y científico del país y de la Región

\footnotetext{
*Correspondence / Correspondencia:

Jorge Albeiro Herrera Builes, Vicerrector Académico Universidad San Buenaventura- Medellín,
}

\section{Indexing / indexaciones}

International Journal of Psychological Research se encuentra incluida en: Scopus, EBSCO (Academic Search Complete), Dialnet, Imbiomed, Doaj, Scirus, New Jour, Ulrichsweb, Pserinfo, Journal Seek, Google scholar. 


\title{
Acreditation in psychology
}

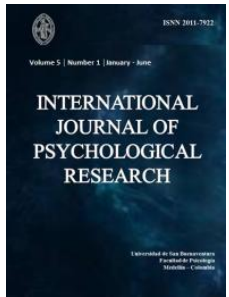

\author{
JoRGE Albeiro HERRERA BUILES *,a \\ ${ }^{a}$ Vicerrector Académico Universidad San Buenaventura-Medellín
}

The INTERNATIONAL JOURNAL OF PSYCHOLOGICAL RESEARCH, serves as a pretext and reference of the main strategic objective of the University of San Buenaventura in Medellín, Colombia for the coming years. And it is in respect to the full Accreditation project of the institution. Since its founding 45 years ago, the Alma Mater has sustained commitment and responsibility to society, to provide quality education under the guiding principles of Franciscan philosophy and permanent improvement of the proposed educational establishment.

In seeking to be recognized for quality, and not just general education programs in the institution that just endorses a pre-existing structural processes that is governed by patterns of classification, categorization, consolidation and verification of methods and techniques to control the homogeneity that guarantee the rigor of the auditing processes. But on the contrary, it is the pretext to generate the internal modifications and transformations necessary to guide the construction of the ideal university we want to project to society.

This is why in recent years it is evident the commitment of the institution to strengthen academia and research, by allowing the accreditation aspect of the Psychology program, it opened the window of the Doctorate in Psychology degree and the inclusion of our journal being indexed in Scopus. These recent results express the relevance and the impact of research of the institution, to the scientific communities worldwide. In this component of investigat ion, the faculty of the Psychology program is very well recognized in the quality of the University of San Buenaventura, not only for the social recognition of their graduates, but by the consolidation of its academic community, bringing together the human, scientific and social contribution to social development in the region.

In gaining accreditation of the Psychology program, it allows an enhanced and motivated teaching experience and research of the institution, ensuring the recognition of the program in the international context. Thus, projecting an updated discipline in the light of scientific advances and paradigm shifts that are reshaping society, culture and individuals. In that sense, it requires permanent innovation in educational strategies and management tools that promote the advancement of psychology as a profession in the face of changes in society. That is, the role of the psychologist in the social fabric as a mediator of appropriate changes in the inter-individuation process as a central promoter of mental health and as a key player in promoting healthy lifestyles by integrating the stages of human development, the innovative challenges of neuroscience and development for deciphering human behavior, and the development of new theoretical and practical models that provide effective interventions for individuals and patterns of vulnerability that arise in the maelstrom of everyday humans.

Therefore, the ongoing pursuit of academic excellence will remain the primary reason that guide the every day decisions and strategies of the University. So therefore, the institution establishes a commitment to the national context and the institutional accreditation of its programs as a way of projecting the role of the Universidad de San Buenaventura in the social, economic, and scientific production in the country and the entire region.

\footnotetext{
* Correspondence / Correspondencia:

Jorge Albeiro Herrera Builes, Vicerrector Académico Universidad San Buenaventura- Medellín,
}

\section{Indexing / indexaciones}

International Journal of Psychological Research se encuentra incluida en: Scopus, EBSCO (Academic Search Complete), Dialnet, Imbiomed, Doaj, Scirus, New Jour, Ulrichsweb, Pserinfo, Journal Seek, Google scholar, y está en proceso de inclusión en diversas bases de datos internacionales. 